University of Nebraska - Lincoln

DigitalCommons@University of Nebraska - Lincoln

Entomology Papers from Other Sources

Entomology Collections, Miscellaneous

1998

Selectivity of Whitefly Traps in Cotton for Eretmocerus eremicus

(Hymenoptera: Aphelinidae), a Native Parasitoid of Bemisia argentifolii (Homoptera: Aleyrodidae)

\author{
K. A. Hoelmer \\ Phoenix Plant Protection Center, c/o Irrigated Desert Research Station, U.S. Department of Agriculture, \\ APHIS, PPQ, 4151 Highway 86, Brawley, CA 92227 \\ W. J. Roltsch \\ Phoenix Plant Protection Center, c/o Irrigated Desert Research Station, U.S. Department of Agriculture, \\ APHIS, PPQ, 4151 Highway 86, Brawley, CA 92227 \\ E. C. Chu \\ Phoenix Plant Protection Center, c/o Irrigated Desert Research Station, U.S. Department of Agriculture, \\ APHIS, PPQ, 4151 Highway 86, Brawley, CA 92227 \\ T. J. Hekneberry \\ Phoenix Plant Protection Center, c/o Irrigated Desert Research Station, U.S. Department of Agriculture, \\ APHIS, PPQ, 4151 Highway 86, Brawley, CA 92227
}

Follow this and additional works at: https://digitalcommons.unl.edu/entomologyother

Part of the Entomology Commons

Hoelmer, K. A.; Roltsch, W. J.; Chu, E. C.; and Hekneberry, T. J., "Selectivity of Whitefly Traps in Cotton for Eretmocerus eremicus (Hymenoptera: Aphelinidae), a Native Parasitoid of Bemisia argentifolii (Homoptera: Aleyrodidae)" (1998). Entomology Papers from Other Sources. 100.

https://digitalcommons.unl.edu/entomologyother/100

This Article is brought to you for free and open access by the Entomology Collections, Miscellaneous at DigitalCommons@University of Nebraska - Lincoln. It has been accepted for inclusion in Entomology Papers from Other Sources by an authorized administrator of DigitalCommons@University of Nebraska - Lincoln. 


\title{
Selectivity of Whitefly Traps in Cotton for Eretmocerus eremicus (Hymenoptera: Aphelinidae), a Native Parasitoid of Bemisia argentifolii (Homoptera: Aleyrodidae)
}

\author{
K. A. HOELMER, W. J. ROLTSCH, ${ }^{1}$ C. C. CHU, ${ }^{2}$ and T. J. HENNEBERRY ${ }^{2}$ \\ Phoenix Plant Protection Center, c/o Irrigated Desert Research Station, U.S. Department of Agriculture, APHIS, PPQ,
} 4151 Highway 86, Brawley, CA 92227

\begin{abstract}
Environ. Entomol. 27(4): 1039-1044 (1998)
ABSTRACT Yellow sticky traps are widely used for monitoring and management of whiteflies and certain other pests and have also been used to monitor their natural enemy activity. A new, nonsticky whitefly trap (CC trap), standard yellow sticky cards, and clear colorless sticky cards were evaluated in cotton (Gossypium hirsutum L.) to compare their attractiveness to Eretmocerus eremicus Rose and Zolnerowich, an aphelinid parasitoid of Bemisia argentifolii Bellows \& Perring [=Bemisia tabaci (Gennadius) B-strain] that is indigenous to southwestern U.S. deserts. The CC traps caught an average of 264 adult whiteflies during 24 -h test periods compared with 523 adult whiteflies on yellow sticky traps. The colorless sticky cards trapped only 37 whiteflies per card during the same period. The CC traps caught an average of 0.4 adult E eremicus over a 24 -h period compared with 26.6 adult E. eremicus trapped by yellow sticky cards. Colorless plastic sticky cards trapped an average of 1.1 parasitoids per card, demonstrating that $E$. eremicus was strongly attracted to the yellow sticky cards. Thirty-nine percent of E. eremicus trapped on yellow sticky cards and $42 \%$ trapped on colorless sticky cards were female. CC traps caught the lowest numbers of other arthropods. On average, $<1$ individual of any other species was captured per CC trap in each 24 -h period. Yellow sticky traps caught the greatest number of other arthropods; these included thrips, flies, cotton leafperforator (Buccalatrix thurberiella Busck) moths, small beetles, and other parasitic wasps. Clear sticky traps caught a similar mixture of species but in lower numbers. These results demonstrate that CC traps are highly selective for whitefly, while preserving parasitoid populations. CC traps may be especially useful in greenhouses where yellow sticky traps are frequently used in conjunction with releases of parasitoids.
\end{abstract}

KEY WORDS Bemisia argentifolii, Eretmocerus eremicus, Aphelinidae, yellow sticky traps, CC trap, cotton

STICKY TRAPS FOR whiteflies are designed to take advantage of the strong whitefly flight response toward yellow (Lloyd 1921, van Lenteren and Noldus 1990) and have been used extensively as tools for sampling populations of many whitefly species (Ekbom and $\mathrm{Xu}$ Rumei 1990), including Bemisia spp. (Gerling and Horowitz 1984, Youngman et al. 1986, Natwick et al. 1995). Yellow sticky traps are also sometimes used by growers specifically to reduce populations of whiteflies and other pests in greenhouses (van de Veire and Vacante 1984, Gillespie and Quiring 1987) and in field crops (Cline 1994, Johnson 1996). Disadvantages of sticky traps include their tendency to become clogged with nontarget insects and wind-blown dirt, the inability to reuse the trap, and the messiness of the glue. Recently a new type of inexpensive, reusable, and

This article reports the results of research only. Mention of a proprietary product does not constitute an endorsement or a recommendation by the USDA for its use

${ }^{1}$ California Department of Food \& Agriculture, Biological Control Program, 4151 Highway 86, Brawley, CA 92227.

${ }^{2}$ Western Cotton Research Laboratory, USDA-ARS, 4135 E. Broadway Road, Phoenix, AZ 85040. glueless cup trap (CC trap) was developed, based both on adult whitefly attraction to yellow and orientation behavior toward light (van Lenteren and Noldus 1990; C.C.C., unpublished data). The trap has been tested extensively for its ability to trap whitefly adults (Chu et al. 1996a, b, 1997). Whiteflies are attracted to the trap's brightly colored yellow base which has a circular hole in its ventral surface opening into the trap interior. After landing, they walk up through the opening toward light (Chu et al. 1998) and into an upper enclosure covered by a detachable, clear colorless plastic cup. Unable to find their way out, many adult whiteflies die inside the trap. These individuals can then be removed and counted.

Yellow traps are known to attract many species of parasitoids, including aphelinids (Neuenschwander 1982, Moreno et al. 1984, Samways 1986, McClain et al. 1990). Yellow traps are attractive to aphelinid and platygasterid parasitoids of citrus blackfly, Aleurocanthus woglumi Ashby (Dowell and Cherry 1981) and were used to monitor field populations of these parasitoids, Encarsia opulenta (Silvestri) and Amitus hesperidum Silvestri (Nguyen et al. 1983). Yellow cards 
are also widely used as monitoring tools in conjunction with releases of parasitoids in greenhouses to reduce populations of the greenhouse whitefly, Trialeurodes vaporariorum (Westwood), and Bemisia argentifolii Perring \& Bellows [ = B. tabaci (Gennadius) B-strain], yet few studies have examined the impact of sticky traps on parasitoids. Yellow traps have been used in addition to releases of Encarsia formosa Gahan against T. vaporariorum to provide high levels of control (van de Veire and Vacante 1984, Boukadida and Michelakis 1994). Because satisfactory control was achieved in tomatoes (Lycopersicon esculentum Mill.) and cucumbers (Cucumis sativus L.), it was suggested that traps were not significantly disruptive to $E$. formosa (Webb and Smith 1980, van de Veire and Vacante 1984). However, Yano (1987) found that control of T. vaporariorum by mass trapping using yellow sticky tape combined with releases of $E$. formosa was not significantly different than with the use of $E$. formosa alone. Webb and Smith (1980) and van de Veire and Vacante (1984), noting that more E. formosa females were trapped as unparasitized whitefly nymphs became less abundant, attributed this to increased searching activity by the parasitoids. Parrella et al. (1991) also found that yellow traps caught large numbers of $E$. formosa that had been released against $B$. argentifolii on poinsettia (Euphorbia pulcherrima Willd. ex Klotzsch) in greenhouses. As many as 200-250 wasps per card were trapped on some dates, representing $>10 \%$ of the wasps released at that time.

With the increased importance in recent years of $B$. argentifolii on field and greenhouse crops, Eretmocerus spp. are receiving more attention as biological control agents of whiteflies (Simmons and Minkenberg 1994; Hoddle et al. 1996, 1998). Although Gerling and Horowitz (1984) noted that few whitefly parasitoids or predators were found on yellow sticky traps placed in and near Bemisia-infested cotton (Gossypium hirsutum L.) in Israel, E. eremicus Rose and Zolnerowich and several indigenous Encarsia spp. were consistently found on yellow sticky traps placed along the perimeter of certain cotton fields in Arizona (Butler et al. 1993; K.A.H., unpublished data). We are unaware of literature specifically addressing the response of $\mathrm{Er}$ etmocerus spp. to yellow sticky traps. Our study compared the selectivity of the CC trap and yellow sticky traps in a cotton field to the predominant indigenous parasitoid of $B$. argentifolii in desert regions of Arizona and California, E. eremicus. This species has been previously referred to in literature as $E$. haldemani Howard, E. californicus Howard, or E. sp. nr. californicus AZ/CA strain (Rose and Zolnerowich 1997).

\section{Materials and Methods}

Thirty rows of cotton ('Delta Pine 5415'), $70 \mathrm{~m}$ in length, were planted in beds spaced $1.08 \mathrm{~m}$ apart at the USDA Irrigated Desert Research Station in Brawley (IDRS), CA, adjacent to a B. argentifolii natural enemy refuge composed of various whitefly host plants. Replicated trials in the cotton were designed to compare the CC traps with standard $7.5-$ by $12.5-\mathrm{cm}$ yellow sticky cards (Olson, Medina, $\mathrm{OH}$ ). The area of the yellow base of the CC trap was $72 \mathrm{~cm}^{2}$; the area of the yellow card was $93.75 \mathrm{~cm}^{2}$. To determine the extent to which the yellow cards trapped parasitoids flying in an undirected manner as opposed to those attracted to the cards, the yellow cards were also compared with translucent, colorless plastic panels of the same size that were coated with an aerosol formulation of Tanglefoot (Insect Trap Coating, Tanglefoot, Grand Rapids, MI). On each of 4 test dates during August 1996, 12 traps of each of the 3 types were fixed to stakes and placed just below canopy level, about $1 \mathrm{~m}$ above ground level at the time of our experiment. This placement was intended to trap primarily local populations of whiteflies and parasitoids. The cotton was not treated with pesticides at any time, and large populations of whiteflies and E. eremicus were present at the start of the study approximately 1 mo before harvest. A randomized design was used to place the 36 traps into 6 rows, each containing 6 traps. Within rows, trap separation was approximately $10 \mathrm{~m}$. Rows containing traps were separated by 2 rows of cotton without traps. Six buffer rows at each edge of the field surrounded the rows in the center of the field containing traps. The $\mathrm{CC}$ traps were hung from a wire arm attached to the stakes with the clear cup above and the yellow base toward the ground. The sticky card traps were attached with wire clips and oriented horizontally with the exposed yellow sticky surface toward the ground. A horizontal, rather than vertical, orientation was chosen because other authors have demonstrated that Bemisia spp. fly near the ground and are more readily trapped using horizontal traps (e.g., Gerling and Horowitz 1984). All traps were set out at $1200 \mathrm{~h}$ on 16, 19, 22, and 26 August 1996 and retrieved after $24 \mathrm{~h}$.

To determine whether the adhesive provided with the commercial yellow cards was comparable in stickiness to the aerosol glue we sprayed onto the clear plastic cards, we conducted a separate test on $28 \mathrm{Au}^{-}$ gust 1996. For this comparison, transparent colorless acetate (plastic wrap) was used to cover the adhesive supplied on 12 yellow traps. This wrap was then sprayed with the aerosol Tanglefoot. These cards were compared with 12 unmodified yellow sticky cards. The traps were placed in the cotton field for $24 \mathrm{~h}$ in a randomized block design as before.

During retrieval from the field, each sticky trap was placed into a clear zip-lock plastic bag to protect the trap contents during transport to the laboratory and during counting. Trap counts were made in the laboratory using a stereomicroscope. CC trap contents were emptied into petri plates for counting. Because condensation of moisture and static electricity caused some of the trapped insects to adhere to the trap, the cup tops and the bases of the traps were also examined by microscope to record the insects remaining on the trap.

Bemesia argentifolii is currently the target of classical biological control introductions in the Imperial Valley, CA. However, although nonindigenous whitefly parasitoids were present at the study site, popula- 
Table 1. Comparison of number of $B$. argentifolii adults trapped with CC traps and sticky card traps

\begin{tabular}{|c|c|c|c|c|c|c|}
\hline 16 Aug. & $344.9 \pm 23.6 a$ & $660.7 \pm 109.8 b$ & $28.5 \pm 4.8 c$ & 26.2 & 2,32 & $<0.001$ \\
\hline 22 Aug. & $287.3 \pm 18.7 \mathrm{a}$ & $481.8 \pm 069.4 \mathrm{~b}$ & $52.8 \pm 8.7 \mathrm{c}$ & 26.4 & 2,33 & $<0.001$ \\
\hline 26 Aug. & $97.7 \pm 12.6 \mathrm{a}$ & $333.0 \pm 0.50 .7 \mathrm{~b}$ & $37.8 \pm 3.9 \mathrm{c}$ & 26.6 & 2,33 & $<0.001$ \\
\hline Grand mean & $264.2 \pm 17.9 \mathrm{a}$ & $522.9 \pm 041.7 \mathrm{~b}$ & $36.8 \pm 3.2 \mathrm{c}$ & 43.6 & 2,6 & $<0.001$ \\
\hline
\end{tabular}

Grand means and treatment means for each date $( \pm \mathrm{SE})$ followed by same letter are not significantly different. All tests shown are Waller-Duncan $k$-ratio $t$-tests preceded by a 1-way ANOVA (by date) or randomized complete block (across all dates).

tions of the native E. eremicus greatly exceeded those of exotic species in our samples, and relatively few exotics were seen on the traps. Therefore, only trap counts of the native species are presented here. Parasitoids were identified by K.A.H. and W.J.R., and voucher specimens have been deposited in the USDA project collection at Brawley.

Data were analyzed by date with a general linear models procedure (SAS Institute 1991) as a randomized design. In addition, data were analyzed across all dates as a randomized complete block design with the 3 trap types as treatments and the four 24 -h sample periods as blocks. All mean separation tests shown in tables are Waller-Duncan $k$-ratio $t$-tests. Analyses by sample date were performed on transformed whitefly and parasitoid counts using a $\log (x+1)$ transformation. Grand means analysis was performed on transformed treatment by date means using a $\log (x+1)$ transformation. Untransformed values are shown in tables. The Satterthwaite approximate $t$-test (unpaired) for unequal variances (SAS Institute 1991) was used to compare the counts of whiteflies and $E$. eremicus trapped by different adhesives used on the commercial yellow sticky cards and on the colorless plastic cards.

\section{Results}

In replicated trials the $\mathrm{CC}$ traps caught an average of 264 adult whiteflies during a 24 -h period compared with 523 adult whiteflies per yellow sticky card. This ratio of $51.0 \%$ is comparable to results obtained in other field trials of the new traps (C.C.C., unpublished data). Colorless cards trapped only 37 whiteflies per card $7.0 \%$ of the number caught on yellow sticky cards and $13.9 \%$ of those caught by CC traps) during the same period (Table 1). The CC traps caught only
0.4 whitefly parasitoids per trap over a 24 -h period compared with an average of 26.6 adult E. eremicus trapped on yellow sticky cards (Table 2). A few native Encarsia luteola Howard and Encarsia meritoria Gahan were also trapped on the sticky cards, but their numbers were very low ( 0.1 adult per card or less). Population densities of both Encarsia spp. in the study plot were low compared with E. eremicus. These results clearly show that although the CC trap captures fewer adult whiteflies in cotton than yellow sticky cards, it effectively traps whitefly adults without capturing adult whitefly parasitoids in significant numbers. The colorless sticky cards trapped an average of only $1.1 \mathrm{E}$. eremicus per card (Table 2 ), demonstrating that adult E. eremicus were indeed attracted to the yellow color and were not caught purely as a result of random flight onto a trap.

Trap counts of both whitefly and E. eremicus adults decreased in CC cup traps and on yellow cards over time, with the highest counts on the 1st sample date and the lowest counts on the final date (Tables 1 and 2 ). The trend of decreasing numbers of whiteflies trapped did not occur on the colorless cards, however; whitefly numbers remained similar from week to week. The average number of E. eremicus on the colorless cards decreased slightly. USDA Irrigated Desert Research Station weather records for each sample date indicated that the weather on each of the 4 sample dates was similar (mean anemometer wind speed of $4.0 \mathrm{~km} / \mathrm{h}$, range $2.1-5.9$; mean daily low $\mathrm{RH}$ of $8 \%$, range $7-9 \%$; mean daily high $\mathrm{RH}$ of $52 \%$, range $42-67 \%$; mean daily low temperature of $26^{\circ} \mathrm{C}$, range $24-28^{\circ} \mathrm{C}$; and mean daily high temperature of $43^{\circ} \mathrm{C}$, range $42-44^{\circ} \mathrm{C}$ ).

On the 1 st sample date, male E. eremicus outnumbered females on both types of sticky traps by a ratio of 2.5:1. However, on all of the other dates females

Table 2. Comparison of number of $E$. eremicus adults trapped with CC traps and sticky card traps

\begin{tabular}{|c|c|c|c|c|c|c|}
\hline Date & \multicolumn{3}{|c|}{ Mean \pm SE no. of $E$. eremicus adults trapped during 24 -h test periods } & \multicolumn{3}{|c|}{ ANOVA results } \\
\hline 16 Aug. & $0.8 \pm 0.4 a$ & $61.5 \pm 6.3 b$ & $2.1 \pm 0.5 \mathrm{c}$ & 152.4 & 2,32 & $<0.001$ \\
\hline 22 Aug. & $0.0 \pm 0.0 \mathrm{a}$ & $18.8 \pm 3.6 \mathrm{~b}$ & $1.2 \pm 0.2 \mathrm{c}$ & 111.5 & 2,33 & $<0.001$ \\
\hline 26 Aug. & $0.1 \pm 0.1 \mathrm{a}$ & $1.8 \pm 0.4 \mathrm{~b}$ & $0.2 \pm 0.1 \mathrm{a}$ & 14.6 & 2,33 & $<0.001$ \\
\hline Grand mean & $0.4 \pm 0.1 \mathrm{a}$ & $26.6 \pm 3.7 \mathrm{~b}$ & $1.1 \pm 0.2 \mathrm{a}$ & 17.1 & 2,6 & $<0.003$ \\
\hline
\end{tabular}

Grand means and treatment means for each date $( \pm \mathrm{SE})$ followed by same letter are not significantly different. All tests shown are Waller-Duncan $k$-ratio $t$-tests preceded by a l-way ANOVA (by date) or randomized complete block (across all dates). 
Table 3. Comparison of numbers of other insects trapped with CC traps and sticky card traps, catches pooled across all dates

\begin{tabular}{|c|c|c|c|}
\hline \multirow[t]{2}{*}{ Insect } & \multicolumn{3}{|c|}{$\begin{array}{l}\text { Mean } \pm \mathrm{SE} \text { of insects } \\
\text { trapped during } 24 \text {-h test periods }\end{array}$} \\
\hline & CC traps & Yellow cards & Clear cards \\
\hline Thysanoptera & $0.54 \pm 0.18$ & $1.17 \pm 0.20$ & $0.71 \pm 0.17$ \\
\hline Diptera & $0.25 \pm 0.07$ & $0.70 \pm 0.14$ & $0.73 \pm 0.15$ \\
\hline $\begin{array}{l}\text { Parasitic } \\
\quad \text { Hymenoptera }^{a}\end{array}$ & $0.08 \pm 0.04$ & $0.36 \pm 0.11$ & $0.33 \pm 0.07$ \\
\hline Coleoptera $^{b}$ & $0.04 \pm 0.03$ & $0.15 \pm 0.07$ & $0.15 \pm 0.06$ \\
\hline Delphastus & $0.00 \pm 0.00$ & $0.30 \pm 0.09$ & $0.00 \pm 0.00$ \\
\hline Spiders & $0.02 \pm 0.02$ & $0.09 \pm 0.05$ & $0.13 \pm 0.06$ \\
\hline Lygus & $0.02 \pm 0.02$ & $0.17 \pm 0.05$ & $0.08 \pm 0.04$ \\
\hline Buccalatrix & $0.00 \pm 0.00$ & $0.21 \pm 0.06$ & $0.00 \pm 0.00$ \\
\hline
\end{tabular}

slightly outnumbered males on traps by 1.14:1. Averaged over all sample dates, the sex ratio of adult $E$. eremicus trapped on cards was 39\% female from yellow sticky traps and $42 \%$ female from colorless traps. Thus, there was no evidence suggesting that sticky traps are more attractive to males than females or vice versa.

The aerosol formulation of Tanglefoot and cardsupplied adhesive did not trap significantly different numbers of whiteflies in the separate comparison of adhesives on saran-covered versus original-adhesive yellow cards (means of 508.3 versus 432.7 adults with the aerosol and card-supplied adhesives, respectively; $t=0.744$, df $=22, P>0.465)$, suggesting that the 2 glues were comparable in stickiness to whiteflies. Trapped E. eremicus means also did not differ statistically (means of 1.0 versus 2.1 adults with the aerosol and card-supplied adhesives, respectively; $t=-1.780$, $\mathrm{df}=14, P>0.097$ ). Therefore, we believe that the colorless cards treated with aerosol adhesive probably provided a reasonable estimate of insects that flew at random into these traps without the influence of attraction to the yellow color of the commercial sticky traps.

In addition to whiteflies and their parasitoids, many other arthropods were trapped by each of the trap types, although in lower numbers. Taxa caught repeatedly are listed in Table 3 . Because numbers were low, these were not specifically identified further except as indicated. CC traps caught the fewest kinds and numbers: $<1$ individual of any arthropod per trap per 24 -h period. Thrips and various Diptera were the most frequently caught insects in CC traps, other than whiteflies. Few beneficial insects of any kind were captured in CC traps. However, a few parasitic wasps and generalist predators often found in cotton, such as Geocoris sp., Nabis sp., and several different spiders, were trapped occasionally. Yellow sticky traps caught the greatest number and variety of other arthropods; these included thrips, flies, cotton leafperforator moths (Buccalatrix thurberiella Busck), Lygus sp., and various small beetles. The colorless traps caught a similar mixture of arthropods in slightly lower numbers. Beneficial insects trapped on the 2 types of sticky cards included various other parasitic wasps and, on yellow sticky cards only, a coccinellid whitefly predator, Delphastus sp.

\section{Discussion}

Weather remained relatively constant during the period of the study and was probably not relevant to the decreasing trap counts over time. However, the final irrigation of the cotton occurred during the 1st week of August, and the cotton plants were drying out during the period of time covered by the samples. This dry-down period probably reduced the successful development and emergence of both whitefly and parasitoid populations in the cotton, with a corresponding reduction in numbers available to respond to the yellow traps. The increasing unsuitability of the cotton as a feeding site may also have increased local flight activity of adult whiteflies and increased the chances of their flying onto the colorless traps in their flight path. Byrne et al. (1996) have shown that factors such as crop drydown can change the response to visual spectral cues and subsequent flight behavior of $B$. argentifolii. This may explain the lack of decreasing trap catches on the colorless traps.

At Brawley, CA, the Delphastus sp. was trapped in low but potentially significant numbers on yellow sticky traps given the size of its local population. This native predator was redistributed from indigenous populations in Arizona in 1995 (Pickett and Roltsch 1996) and previously released into a refuge planting adjacent to the cotton sampled in this study; it subsequently spread into the cotton. Yellow sticky traps are known to be attractive to coccinellids, for example, the Delphastus spp. preying on the citrus blackfly (Dowell and Cherry 1981), and coccinellid predators of several insect pests of olive, Olea europaea L. (Neuenschwander 1982).

The CC traps were highly selective for whitefly without trapping parasitoid populations or other beneficial insects frequently found in desert-planted cotton. In our study they consistently caught about half of the numbers of $B$. argentifolii but only a small percentage of the E. eremicus that were trapped on 7.5by $12.5-\mathrm{cm}$ yellow sticky cards. The CC traps should be very useful for surveys designed specifically to monitor whitefly adults but should not be relied on to monitor whitefly parasitoids or other insects, for which sticky yellow traps are sometimes used. Our results may help to explain observations that CC traps placed into environmental chambers and in a greenhouse to trap stray parasitoids were never observed to contain any whitefly parasitoids (J. Goolsby, personal communication). The discrepancy between our results and those of Gerling and Horowitz (1984) in Israel suggest that further studies comparing the catches of E. eremicus and other Encarsia and Eretmocerus spp. by yellow traps at different whitefly and parasitoid densities would be valuable. Gerling and Horowitz (1984) did not report on the parasitism levels in cotton during their study. Although the size of the parasitoid population or percentage of parasitism was not measured in our study, E. eremicus was 
observed to be very abundant in the cotton. Perhaps yellow sticky traps catch only a small percentage of parasitoids present in cotton, so that large populations must be present for trap catches to be noticeable. Further studies on the relationship between trap catches of parasitoids and actual population levels in crops would provide useful information. Because our results showed that $\mathrm{CC}$ traps are compatible with $E$. eremicus and other natural enemies found in cotton fields, we believe that these traps could also be valuable for use in greenhouses as a replacement for yellow sticky traps when used in combination with releases of natural enemies to maintain whiteflies at low levels. Further studies with CC traps in greenhouse crops are needed to investigate their potential for use under these conditions.

\section{Acknowledgments}

We thank Mike Aguayo (CDFA, Brawley), Mel Marsh, Paul Merten, and Linda Hamrick (USDA, APHIS, Brawley) for assistance with field work, R. Van Driesche (University of Massachusetts) and J. Sanderson (Cornell University) for literature on parasitoid response to traps, and Walker Jones (USDA-ARS, Weslaco, TX) for reviewing a draft of the manuscript.

\section{References Cited}

Boukadida, R., and S. Michelakis. 1994. The use of Encarsia formosa in integrated programs to control the whitefly Trialeurodes vaporariorum Westw. (Hom., Aleyrodidae) on greenhouse cucumber. J. Appl. Entomol. 118: 203-208.

Butler, G. D., O. El-Lissy, and L. Antilla. 1993. Sweetpotato whitefly parasites abundant in some cotton fields during October. Ariz. Agric. Exp. Stn. Rep. P-94: 262-263.

Byrne, D. N., R. J. Rathman, T. V. Orum, and P. C. Palumbo. 1996. Localized migration and dispersal by the sweet potato whitefly, Bemisia tabaci. Oecologia (Berl.) 105: 320-328.

Chu, C. C., T. J. Henneberry, and A. C. Cohen. 1996a. Development and evaluation of a new whitefly trap, p. 20. In T. J. Henneberry, N. C. Toscano, R. M. Faust, and J. R. Coppedge [eds.], Silverleaf whitefly: 1996 supplement to the 5-year national research and action plan-fourth annual review. San Antonio, TX. U.S. Dep. Agric. ARS 199601.

Chu, C. C., T. J. Henneberry, and A. C. Cohen. 1996b. Introduction of a new whitefly trap, p. 335. Proceedings, XX International Congress of Entomology, August 1996, Florence, Italy, Tipographia TAF.

Chu, C. C., T. J. Henneberry, M. A. Boykin, and A. C. Cohen. 1997. A modified new whitefly trap (CC trap) to increase whitefly adult catches, pp. 1247-1248. In P. Duggan and D. A. Ritchter [eds.], Proceedings, Beltwide Cotton Conference, National Cotton Council, Memphis, TN.

Chu, C. C., T. J. Henneberry, and M. A. Boykin. 1998. Response of Bemisia argentifolii (Homoptera: Aleyrodidae) adults to white fluorescent and incandescent light at low light intensities in laboratory studies. Southwest. Entomol. 23: 169-181.

Cline, H. 1994. 'Largest trapping' avoids insecticide on cotton, melons. Calif.-Ariz. Farm Press 16(19): 1, 7, 12.

Dowell, R. V., and R. H. Cherry, 1981. Survey traps for parasitoids, and coccinellid predators of the citrus black- fly, Aleurocanthus woglumi. Entomol. Exp. Appl. 29: 356362.

Ekbom, B. S. and Xu Rumei. 1990. Sampling and spatial patterns of whiteflies, pp. 107-21. In D. Gerling [ed.], Whiteflies: their bionomics, pest status and management. Intercept, Andover, UK.

Gerling, D., and A. R. Horowitz. 1984. Yellow traps for evaluating the population levels and dispersal patterns of Bemisia tabaci (Gennadius) (Homoptera: Aleyrodidae). Ann. Entomol. Soc. Am. 77: 753-759.

Gillespie, D. R., and D. Quiring. 1987. Yellow sticky traps for detecting and monitoring greenhouse whitefly (Homoptera: Aleyrodidae) adults on greenhouse tomato crops. J. Econ. Entomol. 80: 675-679.

Hoddle, M. S., R. G. van Driesche, and J. P. Sanderson. 1996. Greenhouse trials of Eretmocerus californicus Howard (Hymenoptera: Aphelinidae) for control of Bemisia argentifolii Bellows and Perring (Homoptera: Aleyrodidae) on poinsettia in northeastern U.S.A. IOBC/WPRS (Int. Org. Biol. Control/Western Palearctic Reg. Sec.) Bull. 19: $55-58$.

1998. Biological control of Bemisia argentifolii Bellows and Perring (Homoptera: Aleyrodidae) on poinsettia with inundative releases of Eretmocerus eremicus (Hymenoptera: Aphelinidae): do release rates and plant growth affect parasitism? Bull. Entomol. Res. 88: 47-58.

Johnson, B. 1996. Sticking point: a sticky yellow paper is being used to trap flying insects and provide an early warning system for a potential pest invasion. Calif. Farmer 279(11): 32, 34 .

Lloyd, L. 1921. Notes on colour tropism of Asterochiton (Aleurodes) vaporariorum Westwood. Bull. Entomol. Res. 12: 355-359.

McClain, D. C., G. C. Rock, and J. B. Woolley. 1990. Influence of trap color and San Jose scale (Homoptera: Diaspididae) pheromone on sticky trap catches of 10 aphelinid parasitoids (Hymenoptera). Environ. Entomol. 19: 926-931.

Moreno, D. S., W. A. Gregory, and L. K. Tanigoshi. 1984. Flight response of Aphytis melinus (Hymenoptera: Aphelinidae) and Scirtothrips citri (Thysanoptera: Thripidae) to trap color, size, and shape. Environ. Entomol. 13: 935940.

Natwick, E., N. C. Toscano, and L. Yates. 1995. Comparisons of adult whitefly sampling techniques in cotton with whitefly adult populations from whole plant samples. Southwest. Entomol. 20: 33-41.

Neuenschwander, P. 1982. Beneficial insects caught by yellow traps used in mass-trapping of the olive fly, Dacus oleae. Entomol. Exp. Appl. 32: 286-296.

Nguyen, R., J. R. Brazzel, and C. Poucher. 1983. Population density of the citrus blackfly, Aleurocanthus woglumi Ashby (Homoptera: Aleyrodidae), and its parasites in urban Florida in 1979-1981. Environ. Entomol. 12: 878 884

Parrella, M. P., T. D. Paine, J. A. Bethke, K. L. Robb, and J. Hall. 1991. Evaluation of Encarsia formosa (Hymenoptera: Aphelinidae) for biological control of sweetpotato whitefly (Homoptera: Aleyrodidae) on poinsettia. Environ. Entomol. 20: 713-719.

Pickett, C. H., and W. J. Roltsch. 1996. Importation and release of Delphastus spp. for control of the mulberry whitefly and the silverleaf whitefly in California, p. 5. In L. Bezark [ed.], Biological control program annual summary, 1995. California Department of Food and Agriculture, Sacramento, CA

Rose, M., and G. Zolnerowich. 1997. Eretmocerus Haldeman (Hymenoptera: Aphelinidae) in the U.S., with descrip- 
tions of new species attacking Bemisia (tabaci) complex (Homoptera: Aleyrodidae). Proc. Entomol. Soc. Wash. 99(1): $1-27$.

Samways, M. J. 1986. Spatial and temporal population patterns of Aonidiella aurantii (Maskell) (Hemiptera: Diaspididae) parasitoids (Hymenoptera: Aphelinidae and Encyrtidae) caught on yellow sticky traps in citrus. Bull. Entomol. Res. 76: 265-274.

SAS Institute. 1991. SAS/STAT user's guide, release 6.03, 4th ed. SAS Institute, Cary, NC.

Simmons, G. S., and O.P.J.M. Minkenberg. 1994. Field cage evaluation of augmentative biological control of Bemisia argentifolii (Homoptera: Aleyrodidae) in southern California cotton with the parasitoid Eretmocerus nr. californicus (Hymenoptera: Aphelinidae). Environ. Entomol. 23: $1552-1557$.

van de Veire, M., and V. Vacante. 1984. Greenhouse whitefly control through the combined use of the colour attraction system with the parasite wasp Encarsia formosa (Hym.: Aphelinidae). Entomophaga 29: 303-310.

van Lenteren, J. C., and L.P.J.J. Noldus. 1990. Whiteflyplant relationships: behavioural and ecological aspects, pp. 47-89. In D. Gerling [ed.], Whiteflies: their bionomics, pest status and management. Intercept, Andover, UK. Webb, R. E., and F. F. Smith. 1980. Greenhouse whitefly control of an integrated regimen based on adult trapping and nymphal parasitism. U.S.A. IOBC/WPRS (Int. Org. Biol. Control/Western Palearctic Reg. Sec.) Bull. III/3: $235-246$.

Yano, E. 1987. Control of the greenhouse whitefly, Trialeurodes vaporariorum Westwood (Homoptera: Aleyrodidae) by the integrated use of yellow sticky traps and the parasite Encarsia formosa Gahan (Hymenoptera: Aphelinidae). Appl. Entomol. Zool. 22: 159-165.

Youngman, R. R., N. C. Toscano, V. P. Jones, K. Kido, and E. T. Natwick. 1986. Correlations of seasonal trap counts of Bemisia tabaci (Homoptera: Aleyrodidae) in southeastern California. J. Econ. Entomol. 79: 67-70.

Received for publication 23 September 1997; accepted 17 April 1998 